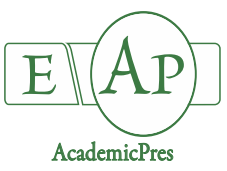

Geng R et al. (2021)

Notulae Botanicae Horti Agrobotanici Cluj-Napoca

Volume 49, Issue 3, Article number 12421

DOI: $10.15835 /$ nbha 49312421

Research Article

\title{
Waterlogging tolerance evaluation of fifteen poplar clones cultivated in the Jianghan Plain of China
}

\author{
Ruonan $\mathrm{GENG}^{1 \mathrm{a}}$, Xinye ZHANG ${ }^{2 \mathrm{~b}}$, Xiaoping FAN ${ }^{3}$, Qian $\mathrm{HU}^{1}$, \\ Tianhong NI ${ }^{1}$, Kebing DU ${ }^{1 *}$
}

\begin{abstract}
${ }^{1}$ Huazhong Agricultural University, College of Horticulture and Forestry Sciences, Hubei Engineering Technology Research Center for Forestry Information, No. 1 Shizishan Street, Hongshan District, Wuhan, China; 935569842@qq.com; 1145823639@qq.com; nitianhong0224@163.com; kebingdu@mail.hzau.edu.cn ("corresponding author)

${ }^{2}$ Hubei Academy of Forestry, 370 Luoyu Road, Hongshan District, Wuhan, China; 1641135733@qq.com

${ }^{3}$ Hubei Academy of Forestry, Shishou Poplar Research Institute, Nanyue Avenue, Shishou City, Jingzhou City, China;971681459@qq.com

${ }^{a, b}$ These authors contributed equally to the work
\end{abstract}

\begin{abstract}
To provide references for poplar cultivation in waterlogged prone area of Jianghan Plain of China, the waterlogging tolerance of 15 poplar clones widely cultivated in these areas were evaluated based on their responses to 45 -day waterlogging stress followed by 15 -day drainage recovery in morphology, growth, biomass accumulation, leaf gas exchange and chlorophyll fluorescence parameters. The results showed that the normal watered seedlings (CK) of the 15 clones grew vigorously during the experiment, and no defoliation and death occurred. For the seedlings under waterlogging treatment (water $10 \mathrm{~cm}$ above the soil surface), its morphology changed markedly, including slowing growth, chlorosis and abscission of leaves, development of hypertrophied lenticels and adventitious roots etc. Waterlogging stress significantly inhibited the seedling growth of height and ground diameter, biomass accumulation, as well as leaf gas exchange and chlorophyll fluorescence parameters of the 15 clones with varying degrees. The net photosynthetic rate $(P n)$, stomatal conductance $(G s)$, transpiration rate $\left(T_{T}\right)$, intercellular $\mathrm{CO}_{2}$ concentration/ environmental $\mathrm{CO}_{2}$ concentration $(\mathrm{Ci} / \mathrm{Ca})$, variable fluorescence $\left(F_{V}\right)$, variable fluorescence/ initial fluorescence $\left(F_{V} / F_{O}\right)$ and PS II primary light energy conversion efficiency $\left(F_{V} / F_{m}\right)$ decreased gradually with the prolonged waterlogging, and reached their bottom on day 45 . During the terminal recovery stage, the leaf gas exchange and chlorophyll fluorescence parameters of the most clones increased, but their recovery abilities were significantly different. At the end of the experiment, the highest survival rates (100\%) were observed in DHY, HS-1, HS-2, I-72, I-69, I-63 and NL-895, and the lowest (zero) occurred in XYY. Survival rates of the other clones ranged from $33.33 \%$ to $83.33 \%$. Both results of cluster analysis and membership function analysis showed that HS-1, I-69, DHY, NL-895 and HS-2 had the strongest waterlogging tolerance, $\mathrm{XYY}$ and $\mathrm{HBY}$ were the worst, and the other clones were moderate. These results would provide guidance not only for the selection of cultivated varieties in Jianghan Plain, but also for the selection of hybrid parents for waterlogging resistance breeding.
\end{abstract}

Keywords: poplar; waterlogging stress; waterlogging tolerance

Received: 02 Jul 2021. Received in revised form: 13 Aug 2021. Accepted: 22 Aug 2021. Published online: 03 Sep 2021.

From Volume 49, Issue 1, 2021, Notulae Botanicae Horti Agrobotanici Cluj-Napoca journal uses article numbers in place of the traditional method of continuous pagination through the volume. The journal will continue to appear quarterly, as before, with four annual numbers. 


\section{Introduction}

Jianghan Plain is located in the central and southern part of Hubei Province of China. It is an important part of the plain in the middle and lower reaches of the Yangtze River, and is one of the lowest plains in China with average altitude of around $27 \mathrm{~m}$. Jianghan Plain has a huge area land prone to waterlogging. Due to the low-lying terrain and excessive seasonal rainfall, waterlogging has become one of the major natural disasters in these areas. Poplar (Populus L.) is one of the most important tree species for afforestation in these areas due to its characteristics of strong waterlogging resistance, rapid growth and broad applications. However, long-term waterlogging stress still adversely affects the growth and survival of poplar seriously (Peng et al., 2018). Under waterlogging stress, due to the lack of oxygen supply to roots, plants often present the phenomenon of leaf chlorosis and abscission, root rotting, photosynthetic capacity decline and so on, which leads to slow growth and even death, coupled with a huge loss of wood yield and ecological function (He et al., 2018; Zhao et al., 2019; Yan et al., 2019).

Previous studies have shown that different poplar clones always possessed significantly different waterlogging tolerance (Gong et al., 2007; Azizi et al., 2017; Sun et al., 2020; Rodriguez et al., 2020). For instance, $P$. deltoides 'Lux' is waterlogging-tolerant, while $P$. simonii is waterlogging-susceptible (Du et al., 2010; Liu et al., 2014; Chen et al., 2015). Male poplar plants tend to have stronger waterlogging tolerance than female ones owing to its lower reproductive costs and energy requirements (Correia and Barradas, 2000; Jiang et al., 2009; Yang et al., 2012). At present, there are more than 15 poplar clones cultivated in Jianghan Plain with different growth performance, which might be related to their different waterlogging tolerance. Therefore, it is of great significance to evaluate the waterlogging tolerance of these clones and select waterlogging-tolerant clones for afforestation and waterlogging resistance breeding in Jianghan Plain. In this study, waterlogging tolerance of 15 poplar clones widely planted in Jianghan Plain were evaluated by investigating their responses to waterlogging stress in morphology, growth, biomass accumulation, together with physiological and ecological characteristics, and waterlogging-tolerant clones were selected as well.

\section{Materials and Methods}

\section{Plant materials and experiments}

The experiment was performed in greenhouse of Huazhong Agricultural University located in Wuhan, Hubei Province $\left(30^{\circ} 28^{\prime} \mathrm{N}, 114^{\circ} 21^{\prime}\right.$ E). The region belongs to Jianghan Plain, and has a warm, temperate climate, with an annual average of 240 frost-free days, $1,269 \mathrm{~mm}$ of rainfall, and a mean yearly temperature of $16.3^{\circ} \mathrm{C}$. Most rainfall occurs between June and August, accounting for about $40 \%$ of the annual rainfall. In a year, the lowest average temperature occurs in January (around $3.0^{\circ} \mathrm{C}$ ) and the highest average temperature occurs in July (around $29.3^{\circ} \mathrm{C}$ ) (Du et al., 2008).

Fifteen poplar clones widely cultivated in Jianghan Plain were adopted as the materials in the present study, including P. simonii (XYY), P. deltoides $50 \times$ P. deltoides 36 (JBY), P. canadensis Moench (JNDY), $P$. ningshanica C. Wang et Tung (HBY), P. deltoides 'Danhong' (DHY), P. Liaoningsis Z. Wang et H. Z. Chen sp. nov (LNY), P. deltoides'Huashi 1' (HS-1), P. deltoides'Huashi 2'(HS-2), P. x euramerican 'San martino'(I72), P. deltoides 'Lux' (I-69), P. deltoides'Harvard'(I-63), P. euramericana 'I-45/51'(I-45/51), P. euramericana 'I-214'(I-214), P. x euramericana 'Nanlin-895' (NL-895), P. deltoides 'Lux' $\times$ P. deltoides 'Shanhaiguan'(ZL2025).

In mid-March, one-year-old shoots of the 15 clones were selected and cut into around $15 \mathrm{~cm}$ cuttings with three to four buds. The cuttings were planted in $15 \mathrm{~cm} \times 20 \mathrm{~cm} \times 15 \mathrm{~cm}$ pots (one cutting per pot) containing mixed soil (natural light loam: sand: peat $=6: 1: 1, \mathrm{pH}=6.2$ ) after soaking in tap water for $24 \mathrm{~h}$, and grown in greenhouse. The soil consisted of $2-5 \% \mathrm{~N}, \mathrm{P}_{2} \mathrm{O}_{5}$ and $\mathrm{K}_{2} \mathrm{O}$, with more than $20 \%$ organic matter (dry weight). After the plants survived, tap water and $1 / 2$ Hoagland nutrient solution were irrigated once a week, 
respectively. The plants with a mean height of $30-40 \mathrm{~cm}$ were randomly assigned to one of two treatments for a 60-day study: (1) watered (CK); (2) partial submergence (PS). In both treatment groups, there were 12 cuttings of each clone (four blocks, three cuttings arranged randomly per block). The pots of the watered treatment group had drainage holes in the bottom, and the plants were watered using tap water every day as needed to maintain soil moisture at around $75 \%$ of the maximum field water capacity. The plants of the waterlogging treatment group were flooded to a depth of $10 \mathrm{~cm}$ above the soil surface in an artificial pond with a depth of $70 \mathrm{~cm}$. To reduce the influence of sunlight on water temperature and to replace the water lost due to evaporation and transpiration, water was continuously supplied to maintain water temperature and waterlogging depth. After 45 days, the waterlogged plants were removed from the partial submergence treatment and allowed to recover for 15 days to simulate natural environmental conditions.

\section{Morphology and growth parameters}

During the waterlogging period, morphological changes of the plants were observed everyday including leaf chlorosis and abscission, development of hypertrophied lenticels and adventitious roots etc. At the end of the experiment, the survival rate of each clone was recorded.

On day zero, 45 and 60, the seedling height and ground diameter of all clones were measured to calculate its growth parameters during the experiment. At the end of recovery stage $(60 \mathrm{~d})$, all of the plants were harvested. Root, stem, and leaf components were dried and weighed. In addition, the stem and its leaves were combined as a total shoot value, that is shoot weight $=$ leaf weight + stem weight, and total biomass $=$ shoot weight + root weight (Rodriguez et al., 2020).

\section{Measurement of leaf gas exchange and chlorophyll fluorescence}

On the $0,15^{\text {th }}, 30^{\text {th }}, 45^{\text {th }}$ and $60^{\text {th }}$ day of waterlogging treatment, the $5^{\text {th }}$ fully expanded and mature leaf from the top of the stem of each clone was chosen to measure leaf gas exchange and chlorophyll fluorescence (Peng et al., 2018). For leaf gas exchange measurement, four plants per clone per treatment were measured between 9:00 am. and 11:30 am. using a LI-6400 photosynthesis system (LI-COR Inc., Lincoln, NE, USA) with a standard LI-COR gas exchange chamber $(2 \times 3 \mathrm{~cm})$. A $1500 \mu \mathrm{mol} \cdot \mathrm{m}^{-2} \cdot \mathrm{s}^{-1}$ light intensity of illumination was provided by red diodes (6400-02 LED Source), and the gas flow rate was set as $500 \mu \mathrm{mol} \cdot \mathrm{s}^{-1}$. The gas exchange measurements included net photosynthetic rate $\left(P_{n}\right)$, transpiration rate $\left(T_{T}\right)$, stomatal conductance $(G s)$, intercellular $\mathrm{CO}_{2}$ concentration/ environmental $\mathrm{CO}_{2}$ concentration $(\mathrm{Ci} / \mathrm{Ca})$, and the corresponding ambient environmental conditions, such as leaf surface temperature, photosynthetically active radiation, relative atmospheric temperature and relative humidity. Chlorophyll fluorescence of leaves of four plants per treatment per clone was measured using a LI-6400 fluorescence system (LI-COR Inc., USA) after a 20-min dark adaptation under natural conditions, including variable fluorescence $\left(F_{V}\right)$, PSII primary light energy conversion efficiency $\left(F_{V} / F_{m}\right)$, variable fluorescence to initial fluorescence ratio $\left(F_{V} / F_{O}\right)$ and so on.

\section{Statistical analysis}

The data were analyzed by analysis of variance (ANOVA) and multiple comparisons (Duncan's) with SAS statistical software package version 9.0 (SAS Institute Inc., USA). The waterlogging tolerance of each clone was evaluated by the waterlogging tolerance indexes and membership function values. The waterlogging tolerance index $(\%)=$ average value of waterlogging treatment/ average value of watered treatment $\times 100 \%$ (Rodriguez et al, 2020). The calculation formula of membership function value is $U\left(x_{i}\right)=\left(x-X_{\min }\right) /\left(x_{\max }-X_{\min }\right)$ or $U\left(x_{i}\right)=1-\left(x-x_{\min }\right) /\left(x_{\max }-X_{\min }\right)$ for the index which has a positive or negative correlation with waterlogging tolerance, respectively. $U\left(x_{i}\right)$ represents the membership function value of an index of clone $i ; x$ represents the mean value of an index of clone $i ; x_{\max }$ and $x_{\min }$ are, respectively, the maximum and minimum values of an index in all clones (Yan et al., 2020). The cluster analysis of waterlogging tolerance of the 15 clones was carried out based on multivariate analysis (minimum distance method) of all data obtained during the study (Du et al., 2008). 


\section{Results}

\section{Plant morphology}

All watered plants (CK) grew vigorously, and no defoliation occurred. At the end of the experiment, the survival rates of all CK plants were $100 \%$. In terms of waterlogged plants, obvious morphological changes were observed, including chlorosis and abscission of leaves, as well as development of hypertrophied lenticels and adventitious roots. Most clones firstly appeared hypertrophied lenticels on the $5^{\text {th }}-6^{\text {th }}$ day of waterlogging treatment, together with chlorosis leaves on the $10^{\text {th }}-13^{\text {th }}$ day, and defoliation on the $19^{\text {th }}-20^{\text {th }}$ day (Table 1$)$. At the end of drainage recovery, DHY, HS-1, HS-2, I-72, I-69, I-63 and NL-895 displayed the highest survival rates (100\%); XYY owned the lowest survival rate (0\%), and that of the other clones ranged from $33.33 \%$ to $83.33 \%$. Among the 15 clones, all plants of XYY and some plants of HBY and I-214 died during the waterlogging treatment, and XYY died earliest on day 32. Some plants of JBY, JNDY, LNY, I-45/51 and ZL2025 died during drainage recovery.

Table 1. Morphological responses to waterlogging stress of the 15 poplar clones

\begin{tabular}{|c|c|c|c|c|c|}
\hline Clone & $\begin{array}{l}\text { Initial time of leaf } \\
\text { chlorosis }(\mathrm{d})\end{array}$ & $\begin{array}{l}\text { Initial time of } \\
\text { defoliation }(d)\end{array}$ & $\begin{array}{c}\text { Initial time of } \\
\text { hypertrophied lenticels } \\
\text { development }(\mathrm{d})\end{array}$ & $\begin{array}{l}\text { Initial time of } \\
\text { adventitious root } \\
\text { formation }(\mathrm{d})\end{array}$ & $\begin{array}{c}\text { Survival rate } \\
(\%)\end{array}$ \\
\hline XYY & 8 & 16 & 7 & 17 & 0 \\
\hline JBY & 10 & 19 & 6 & 15 & 75 \\
\hline JNDY & 8 & 16 & 6 & 15 & 83.33 \\
\hline HBY & 9 & 17 & 6 & 17 & 33.33 \\
\hline DHY & 11 & 19 & 5 & 10 & 100 \\
\hline LNY & 10 & 20 & 6 & 16 & 75 \\
\hline HS-1 & 14 & 21 & 5 & 10 & 100 \\
\hline HS-2 & 15 & 22 & 5 & 10 & 100 \\
\hline I-72 & 10 & 18 & 6 & 12 & 100 \\
\hline$I-69$ & 14 & 21 & 5 & 10 & 100 \\
\hline I-63 & 13 & 20 & 6 & 11 & 100 \\
\hline $\mathrm{I}-45 / 51$ & 12 & 19 & 6 & 16 & 83.33 \\
\hline I- 214 & 12 & 19 & 6 & 16 & 66.67 \\
\hline NL-895 & 10 & 19 & 6 & 11 & 100 \\
\hline ZL-2025 & 13 & 21 & 7 & 15 & 83.33 \\
\hline
\end{tabular}

Note: $n=12$.

\section{Plant growth}

Growth of height and ground diameter

Height growth of the 15 clones was significantly inhibited by waterlogging treatment to varying degrees ( $p<0.05$; Figure 1). Among them, DHY, HS-1, HS-2 and NL-895 had better waterlogging tolerance indexes, which were $85.63 \%, 87.32 \%, 87.14 \%$ and $84.59 \%$, individually; $\mathrm{HBY}$ and XYY showed the lowest waterlogging tolerance indexes, which were $42.06 \%$ and $37.56 \%$ respectively; while that of the other clones ranged from $60 \%$ to $80 \%$ (Supplementary Table 1). According to the waterlogging tolerance indexes, the slightest inhibition occurred in HS-1, and the most severe inhibition happened in XYY.

Waterlogging treatment significantly reduced ground diameter growth of the 15 clones with different degrees $(p<0.05$; Figure 1). Among them, waterlogging tolerance indexes in XYY and HBY were lower than $60 \%$, and the lowest value occurred in XYY (-9.63\%); DHY, LNY, HS-1, HS-2 and I-69 had higher 
waterlogging tolerance indexes ( $>80 \%$ ), and that of the other clones ranged from $60 \%$ to $80 \%$ (Supplementary Table 1). These waterlogging tolerance indexes indicated that the ground diameter growth of XYY was most affected by waterlogging stress, while that of DHY, LNY, HS-1, HS-2 and I-69 were least affected.
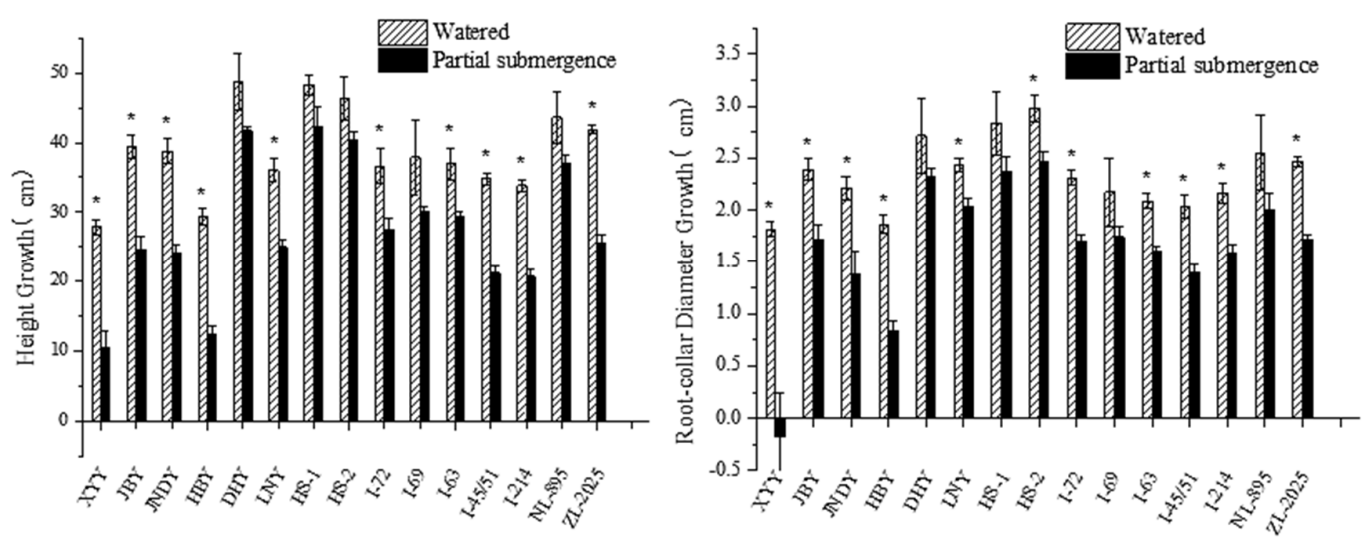

Figure 1. Height and ground diameter growth of the 15 poplar clones under waterlogging treatment Note: Bars labeled with ${ }^{*}$ and ${ }^{* *}$ indicated significant difference between watered and waterlogged seedlings of the same clone at $p<0.05$ and $p<0.01$, respectively ( $t$ test; Mean \pm SE, $n=4$; the same below)

\section{Biomass accumulation}

Waterlogging stress significantly reduced the biomass accumulation and root/shoot ratio in all of the 15 clones, and the reduction levels significantly varied between them $(p<0.05$; Table 2$)$. The highest waterlogging tolerance indexes of root biomass were observed in DHY (73.60\%,), HS-1 (73.41\%), HS-2 (70.59\%), I-69 (73.23\%) and NL-895 (71.02\%), and the lowest were observed in XYY (7.25\%) and HBY (16.50\%), respectively (Supplementary Table 1). For stem biomass, the highest waterlogging tolerance index occurred in NL-895 (86.20\%), and the lowest occurred in XYY (30.45\%) and HBY (34.90\%), respectively. In terms of leaf biomass, DHY (84.45\%) owned the highest waterlogging tolerance index, and XYY (0) has the lowest value, followed by HBY (30.60\%). The waterlogging tolerance indexes of root/shoot ratio mostly concentrated in $60 \%-90 \%$, with the exception of XYY (53.85\%), HBY (50.00\%) and HS-1 (88.37\%). Among the 15 clones, I-69 (81.23\%), DHY (80.42\%) and HS-1 (80.69\%) had more than $80 \%$ of waterlogging tolerance indexes in total biomass, and XYY was the lowest, only $12.54 \%$ (Supplementary Table 1).

Table 2. Biomass accumulation of the 15 poplar clones under waterlogging treatment

\begin{tabular}{|l|c|c|c|c|c|c|}
\hline \multirow{2}{*}{ Clones } & \multirow{2}{*}{ Treatments } & \multicolumn{3}{|c|}{ Biomass $(\mathrm{g})$} & \multirow{2}{*}{$\begin{array}{c}\text { Root/shoot } \\
\text { ratios }\end{array}$} & $\begin{array}{c}\text { Total biomass } \\
(\mathrm{g})\end{array}$ \\
\cline { 3 - 6 } & & Root & Stem & Leaf & $0.26 \pm 0.07$ & $6.70 \pm 0.23$ \\
\hline \multirow{3}{*}{ XYY } & CK & $1.38 \pm 0.04$ & $2.43 \pm 0.08$ & $2.89 \pm 0.24$ & 0.23 & $0.84 \pm 0.14$ \\
\hline \multirow{3}{*}{ JBY } & PS & $0.10 \pm 0.03$ & $0.74 \pm 0.27$ & $0.00 \pm 0.00$ & $0.14 \pm 0.03$ & $9.54 \pm 0.39$ \\
\cline { 2 - 6 } & CK & $2.60 \pm 0.27$ & $3.56 \pm 0.25$ & $3.38 \pm 0.14$ & $0.37 \pm 0.03$ & $6.21 \pm 0.36$ \\
\hline \multirow{2}{*}{ JNDY } & PS & $1.19 \pm 0.12$ & $2.41 \pm 0.25$ & $2.61 \pm 0.15$ & $0.24 \pm 0.02$ & $9.87 \pm 0.51$ \\
\cline { 2 - 6 } & CK & $2.55 \pm 0.26$ & $3.97 \pm 0.34$ & $3.35 \pm 0.15$ & $0.35 \pm 0.04$ & $6.51 \pm 0.51$ \\
\hline \multirow{2}{*}{ HBY } & PS & $1.21 \pm 0.25$ & $2.67 \pm 0.35$ & $2.63 \pm 0.07$ & $0.23 \pm 0.04$ & $7.72 \pm 0.33$ \\
\cline { 2 - 6 } & CK & $2.06 \pm 0.07$ & $2.98 \pm 0.24$ & $2.68 \pm 0.11$ & $0.36 \pm 0.07$ & $2.20 \pm 0.45$ \\
\hline \multirow{2}{*}{ DHY } & PS & $0.34 \pm 0.25$ & $1.04 \pm 0.25$ & $0.82 \pm 0.04$ & $0.18 \pm 0.06$ & $11.34 \pm 0.27$ \\
\cline { 2 - 6 } & PS & $3.56 \pm 0.24$ & $4.05 \pm 0.09$ & $3.73 \pm 0.10$ & $0.46 \pm 0.02$ & $9.12 \pm 0.41$ \\
\hline
\end{tabular}


Geng R et al. (2021). Not Bot Horti Agrobo 49(3):12421

\begin{tabular}{|l|c|c|c|c|c|c|}
\hline \multirow{3}{*}{ LNY } & CK & $2.54 \pm 0.20$ & $3.68 \pm 0.15$ & $3.37 \pm 0.14$ & $0.36 \pm 0.02$ & $9.59 \pm 0.36$ \\
\cline { 2 - 7 } & PS & $1.17 \pm 0.12$ & $2.76 \pm 0.24$ & $2.29 \pm 0.08$ & $0.23 \pm 0.02$ & $6.22 \pm 0.38$ \\
\hline \multirow{3}{*}{ HS-1 } & CK & $3.61 \pm 0.21$ & $4.76 \pm 0.11$ & $3.54 \pm 0.17$ & $0.43 \pm 0.02$ & $11.91 \pm 0.27$ \\
\cline { 2 - 7 } & PS & $2.65 \pm 0.17$ & $3.98 \pm 0.25$ & $2.98 \pm 0.19$ & $0.38 \pm 0.04$ & $9.61 \pm 0.45$ \\
\cline { 2 - 7 } HS-2 & CK & $4.08 \pm 0.09$ & $4.37 \pm 0.41$ & $3.62 \pm 0.30$ & $0.51 \pm 0.05$ & $12.07 \pm 0.78$ \\
\hline \multirow{3}{*}{ I-72 } & CK & $2.88 \pm 0.20$ & $3.66 \pm 0.15$ & $2.75 \pm 0.12$ & $0.45 \pm 0.06$ & $9.29 \pm 0.11$ \\
\hline \multirow{3}{*}{ I-69 } & PS & $1.42 \pm 0.15$ & $2.04 \pm 0.31$ & $2.31 \pm 0.21$ & $0.33 \pm 0.04$ & $5.77 \pm 0.46$ \\
\hline \multirow{3}{*}{ I-63 } & CK & $2.54 \pm 0.06$ & $4.58 \pm 0.20$ & $2.79 \pm 0.10$ & $0.34 \pm 0.02$ & $9.91 \pm 0.23$ \\
\hline \multirow{2}{*}{ I-45/51 } & PS & $1.86 \pm 0.03$ & $3.91 \pm 0.05$ & $2.28 \pm 0.13$ & $0.30 \pm 0.02$ & $8.05 \pm 0.17$ \\
\cline { 2 - 7 } & PS & $2.38 \pm 0.09$ & $3.96 \pm 0.26$ & $3.50 \pm 0.10$ & $0.32 \pm 0.07$ & $9.84 \pm 0.17$ \\
\hline \multirow{2}{*}{ I-214 } & CK & $1.56 \pm 0.13$ & $3.26 \pm 0.13$ & $2.87 \pm 0.17$ & $0.25 \pm 0.03$ & $7.69 \pm 0.16$ \\
\hline \multirow{2}{*}{ NL-895 } & CK & $1.31 \pm 0.20$ & $2.06 \pm 0.29$ & $1.66 \pm 0.15$ & $0.35 \pm 0.03$ & $5.03 \pm 0.26$ \\
\cline { 2 - 7 } & PS & $1.34 \pm 0.06$ & $1.99 \pm 0.16$ & $1.84 \pm 0.16$ & $0.35 \pm 0.06$ & $5.17 \pm 0.31$ \\
\hline \multirow{2}{*}{ ZL-2025 } & CK & $2.83 \pm 0.22$ & $4.13 \pm 0.44$ & $4.31 \pm 0.14$ & $0.34 \pm 0.01$ & $11.27 \pm 0.40$ \\
\cline { 2 - 7 } & PS & $2.01 \pm 0.18$ & $3.56 \pm 0.24$ & $3.14 \pm 0.08$ & $0.30 \pm 0.03$ & $8.71 \pm 0.14$ \\
\hline
\end{tabular}

Note: Mean \pm S.E., $n=4$.

\section{Gas exchange of leaves}

\section{Net photosynthetic rate}

Waterlogging stress adversely affected net photosynthetic rates $\left(P_{n}\right)$ of the 15 clones with significantly different levels $(p<0.05$; Figure 2$)$. The $P n$ values in the most plants decreased gradually with the prolonged waterlogging, and reached their minimum values on day 45. XYY and HBY decreased rapidly from the beginning of waterlogging, while the other clones decreased slower, and some clones even showed small fluctuations (Figure 2). On day 45, the lowest and the highest waterlogging tolerance indexes in $P_{n}$ values were observed in XYY (17.49\%) and I-69 (83.97\%), respectively (Supplementary Table 2). During the terminal recovery stage, $P_{n}$ values of I-63 and NL-895 increased obviously, while that of JBY, HBY and I-72 sustainedly declined. At the end of the experiment (60d), Pn values of all clones were still significantly lower than their CK values, except for I-69 and NL-895. Because all plants of XYY were dead during the waterlogging treatment (before recovery stage), it had no value on day 60 for all parameters of leaf gas exchange and chlorophyll fluorescence.

\section{Transpiration rate}

Similar with $P_{n}$ values, waterlogging dramatically decreased values of transpiration rates $\left(T_{T}\right)$ in the 15 clones, and their responses differed significantly ( $p<0.05$; Figure 3). During the experiment, the $T_{r}$ values of all clones gradually decreased with the prolonged waterlogging, and reached their bottom on day 45 . At that time, the lowest waterlogging tolerance index of $T_{r}$ occurred in XYY (20.24\%), and the highest occurred in I69 (86.23\%; Supplementary Table 2). After waterlogging removed, $T_{r}$ values of the most clones increased in varying degrees. At the end of recovery stage, $T_{r}$ values in the most clones almost recovered to the CK level, with the exception of JNDY, HBY, I-72 and I-63. 

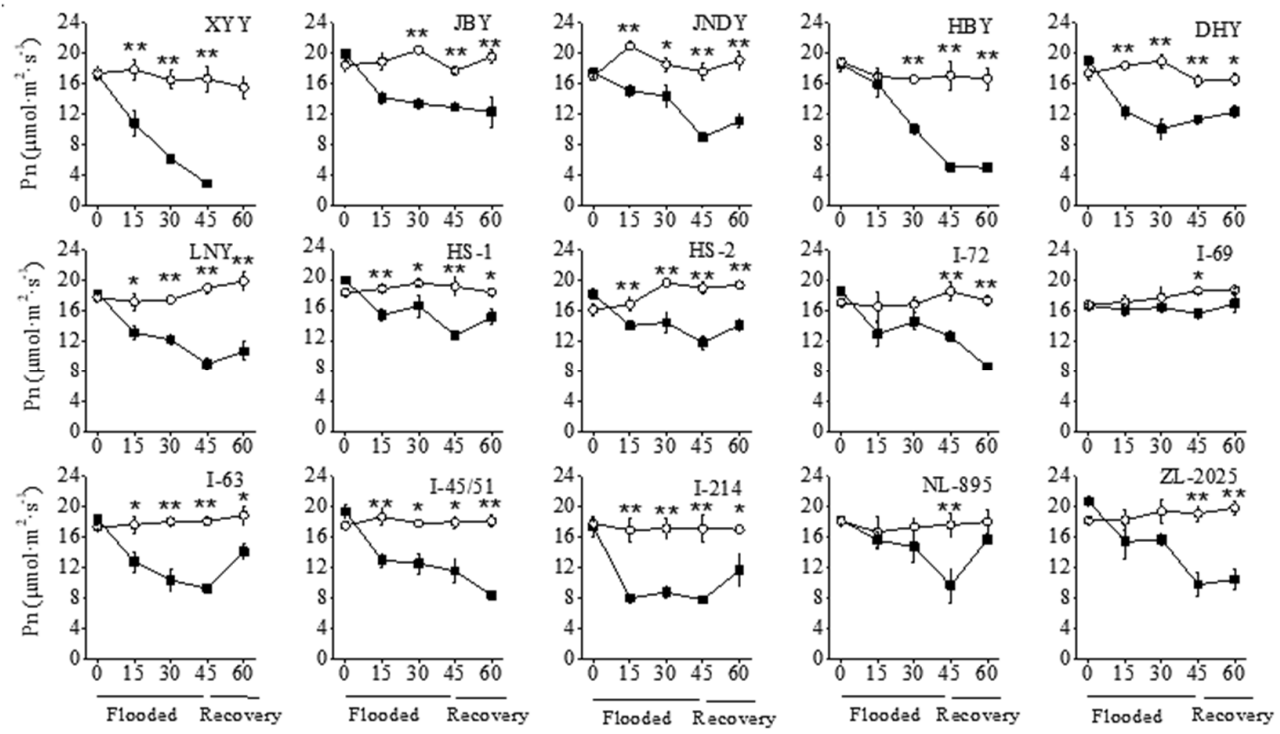

Figure 2. Responses of leaf net photosynthesis rates $\left(P_{n}\right)$ of the 15 poplar clones to waterlogging stress Note: $\bigcirc:$ Watered (CK); •: Partial submergence treatment (PS); the same below
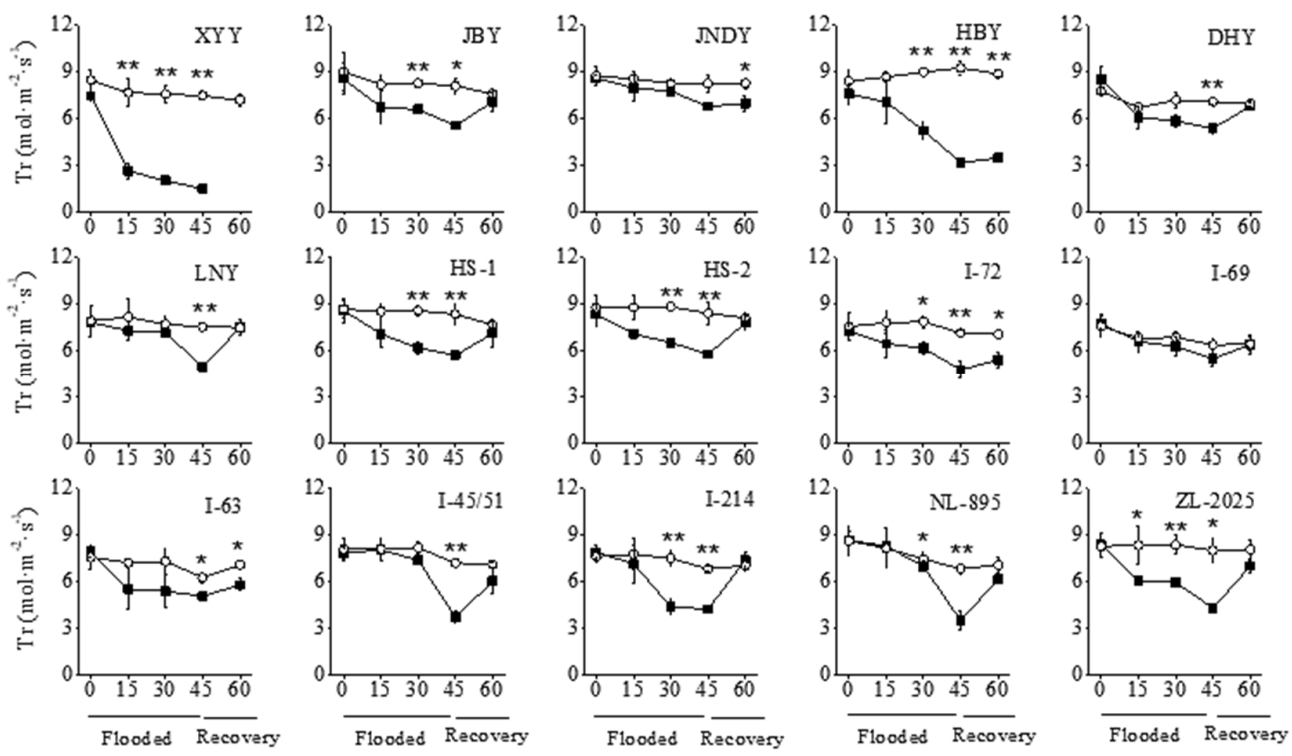

Figure 3. Responses of transpiration rate $\left(T_{T}\right)$ of the 15 poplar clones to waterlogging stress

Stomatal conductance

Stomatal conductance $(G s)$ of the 15 clones was inhibited by waterlogging stress with significantly different degrees in the present study ( $p<0.05$; Supplementary Table 1). The $G s$ values of the most waterlogged plants declined slowly with the prolonged waterlogging, except for slight fluctuation in a few clones, such as in JBY, JNDY and LNY on day 30. On the $45^{\text {th }}$ day, the lowest waterlogging tolerance index of $G s$ value was observed in XYY (19.11\%), and the highest happened in HS-1 (77.62\%; Supplementary Table 2). During the terminal recovery stage, most of the clones did not recover obviously, even continuously decreased, in addition to DHY, HS-1, HS-2, I-69 and NL-895. At the end of the experiment, $G s$ values of the most clones were still dramatically lower than the CK level, except for HS-1, HS-2, I-69 and NL-895. 

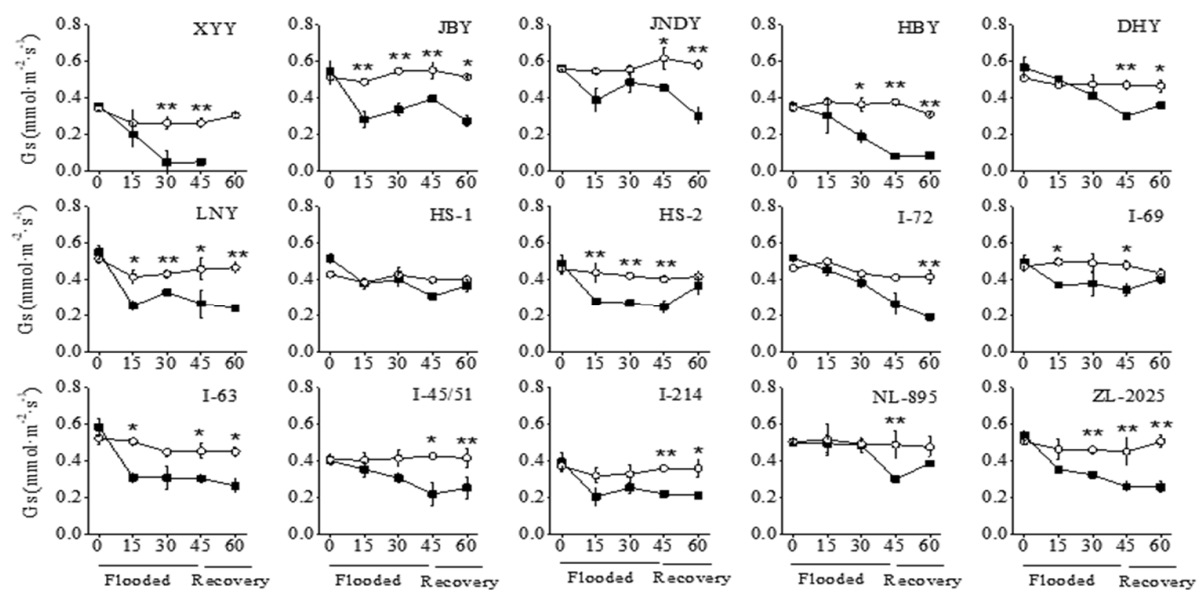

Figure 4. Responses of stomatal conductance $(G S)$ of the 15 poplar clones to waterlogging stress

\section{Intercellular $\mathrm{CO}_{2}$ concentration/ambient $\mathrm{CO}_{2}$ concentration}

Waterlogging stress significantly reduced the intercellular $\mathrm{CO}_{2}$ concentration/ environmental $\mathrm{CO}_{2}$ concentration $(\mathrm{Ci} / \mathrm{Ca})$ of the 15 clones, and their responses differed significantly as well $(p<0.05$; Figure 5$)$. Except for XYY, HBY, HS-2 and I-214, $C i / C a$ values of the most clones changed slightly. On day 45, the lowest and the highest waterlogging tolerance indexes of $C i / C a$ were observed in XYY (66.89\%) and JBY (99.11\%), respectively (Supplementary Table 2). At the end of the recovery stage, $C i / C a$ values of the most clones recovered to their CK levels, with the exception of JBY, HBY, LNY, I-63 and I-214.
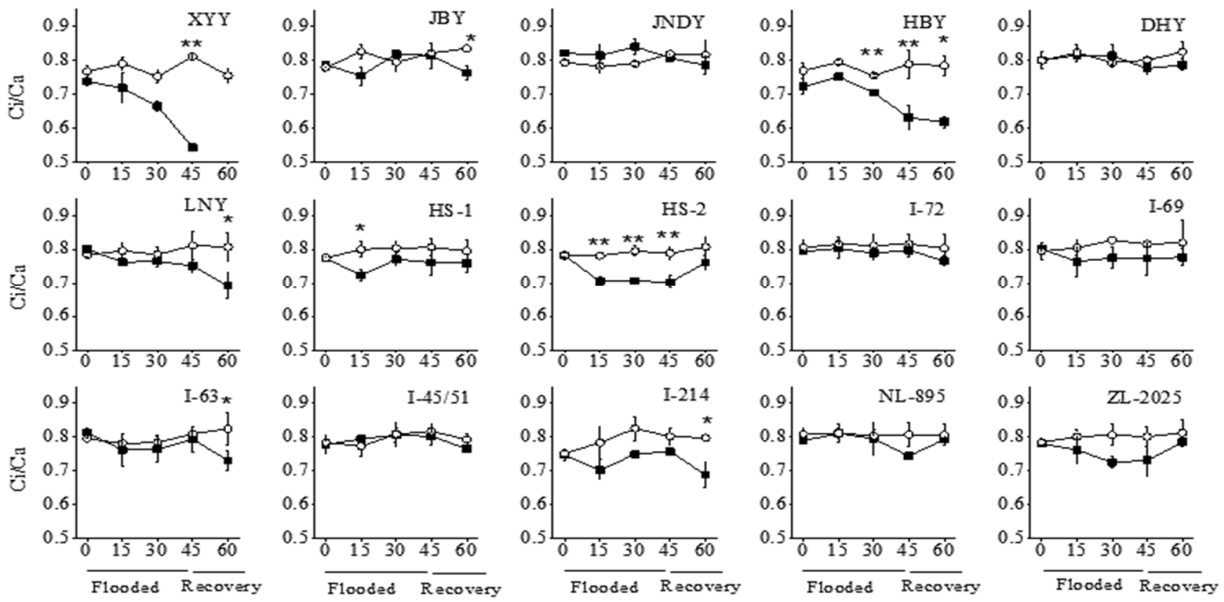

Figure 5. Responses of ratio of internal and atmospheric $\mathrm{CO}_{2}$ concentrations $(\mathrm{Ci} / \mathrm{Ca}$ ) of the 15 poplar clones to waterlogging stress

\section{Chlorophyll fluorescence of leaves}

\section{Variable fluorescence}

Similar with the gas exchange parameters, variable fluorescence $\left(F_{V}\right)$ of waterlogged plants of the 15 clones were dramatically reduced with the prolonged waterlogging $(p<0.05)$, except for the slight decrease in DHY, HS-1, I-72, I-69 and NL-895 (Figure 6). On the $45^{\text {th }}$ day, the lowest waterlogging tolerance index of $F_{V}$ value happened in XYY (66.02\%), and the highest occurred in DHY (92.61\%; Supplementary Table 2). During the terminal recovery stage, most of the clones recovered their $F_{V}$ values, and returned to the CK level on day 60 . 

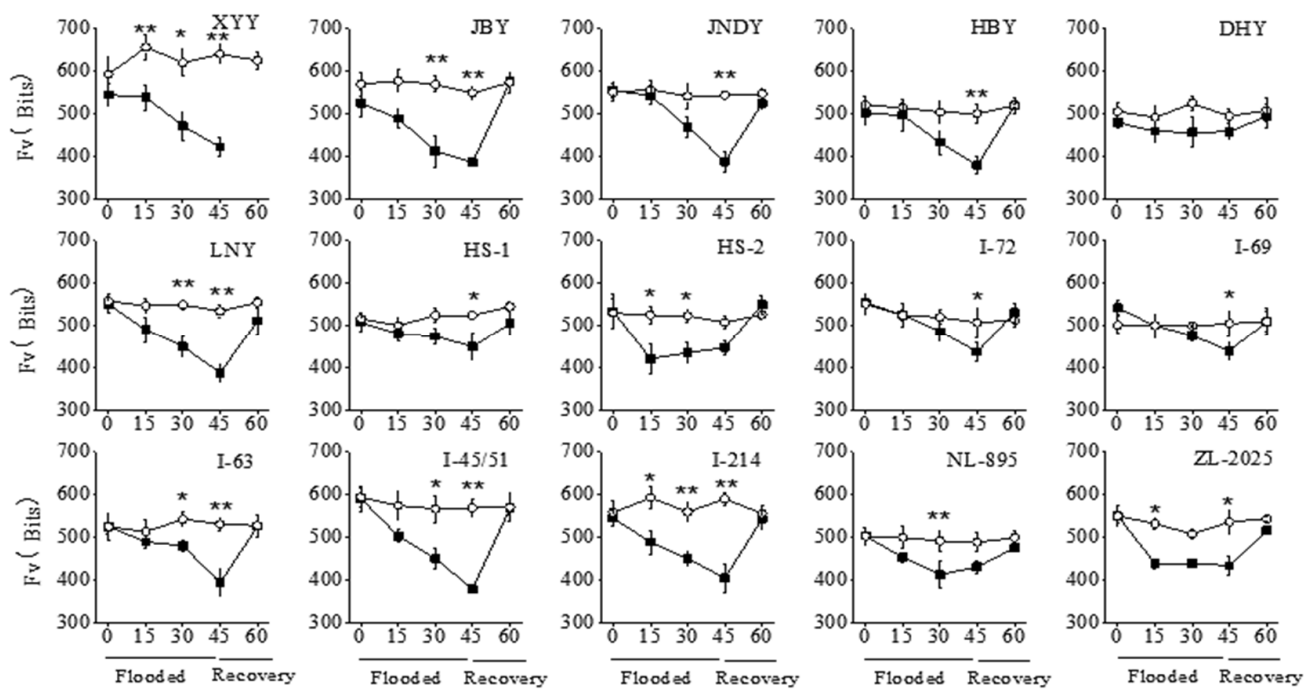

Figure 6. Responses of variable fluorescence $\left(F_{V}\right)$ of the 15 poplar clones to waterlogging stress

\section{Variable fluorescence/ initial fluorescence}

$F_{V} / F_{O}$ values of the 15 clones were significantly reduced under the waterlogging treatment by different degrees ( $p<0.05$; Figure 7 ). Most of the clones slowly decreased their $F_{V} / F o$ with the prolonged waterlogging, and reached their minimum values on day 45 . While, HBY declined sharply during 30-45d, and I-69 varied slightly throughout the experiment. On the $45^{\text {th }}$ day, HBY (39.08\%) and I-69 (92.51\%) exhibited the lowest and the highest waterlogging tolerance index of $F_{V} / F_{O}$, respectively (Supplementary Table 2). At the end of the recovery stage, most of the clones recovered to their CK levels, with the exception of JNDY and HBY.

\section{Primary conversion efficiency of PS II}

In parallel with the changes of $F_{V \text { values, }}$ PS II original light energy conversion efficiency $\left(F_{V} / F_{m}\right)$ of the 15 clones were adversely affected by waterlogging stress with significantly varied levels $(p<0.05$; Figure 8 ). $F_{V} / F m$ values of the most clones decreased severely with the prolonged waterlogging treatment, and reached the lowest values on day 45, with the exception of HS-1, HS-2, I-72 and I-69. On day 45, the lowest waterlogging tolerance index of $F_{V} / F m$ happened in I-214 (71.02\%), and the highest happened in I-69 (99.73\%; Supplementary Table 2). At the end of the recovery stage, most of the clones recovered to the CK level, except for HBY and LNY. 

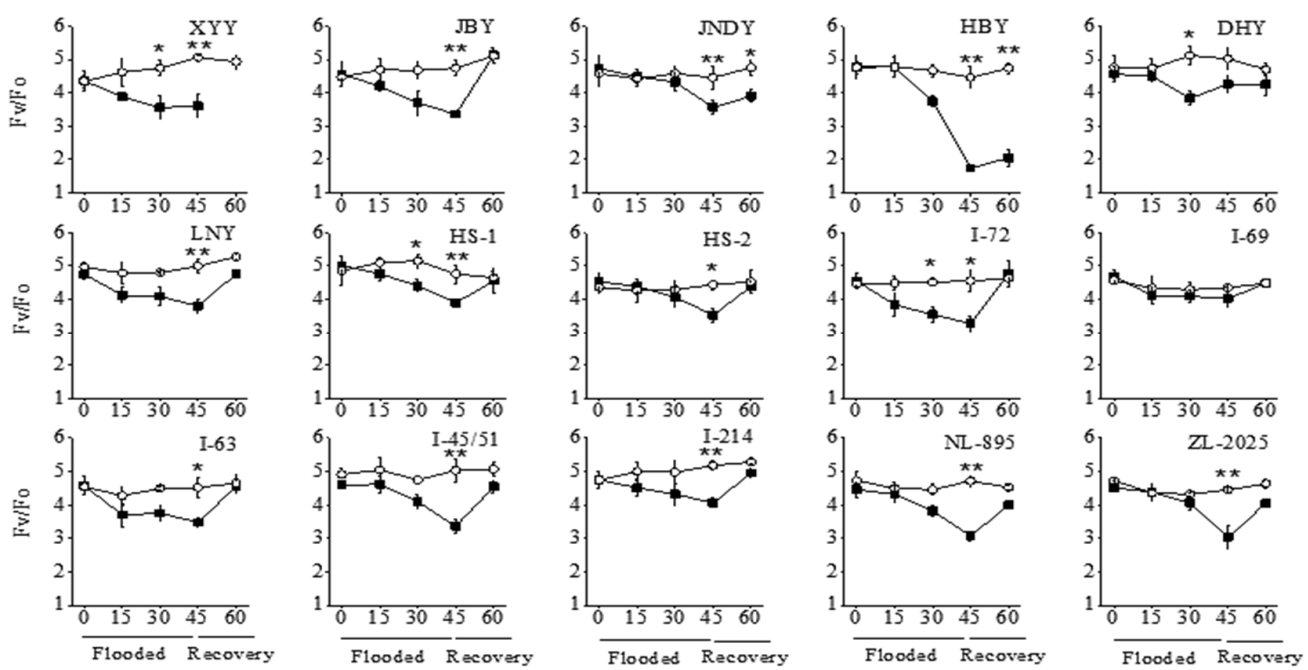

Figure 7. Responses of ratio of variable fluorescence to initial fluorescence $\left(F_{V} / F_{O}\right)$ of the 15 poplar clones under waterlogging treatment
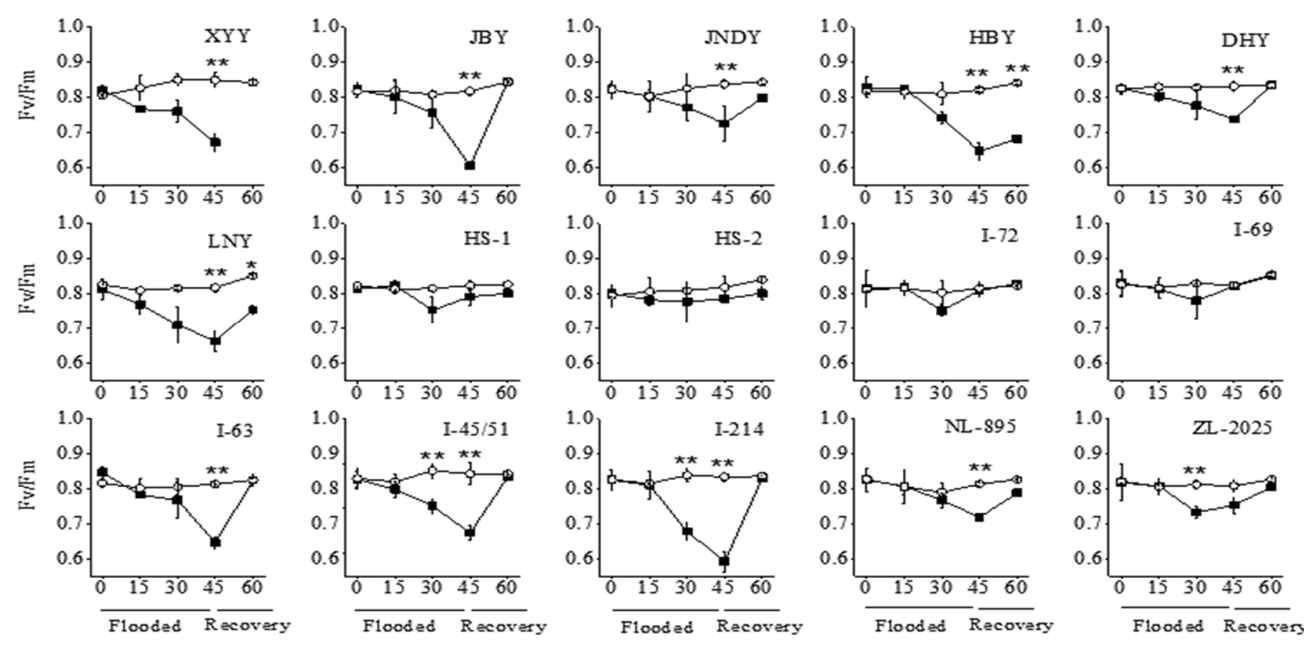

Figure 8. Responses of efficiency of primary conversion of light energy of PS II $\left(F_{V} / F_{m}\right)$ of the 15 poplar clones to waterlogging stress

\section{Cluster analysis of waterlogging tolerance}

Based on the survival rates, coupled with the waterlogging tolerance indexes in height and ground diameter growth, biomass accumulation, as well as leaf gas exchange and chlorophyll fluorescence parameters on day 45, the 15 clones were classified into three groups by multivariate analysis (minimum distance method). XYY and HBY comprised the first group with susceptible waterlogging tolerance. JBY, JNDY, LNY, I-214, I45/51, I-63 and ZL-2025 comprised the second group with moderate waterlogging tolerance. The third group was consisted of DHY, HS-2, HS-1, I-72, NL-895 and I-69, which has the strongest waterlogging tolerance (Figure 9). 


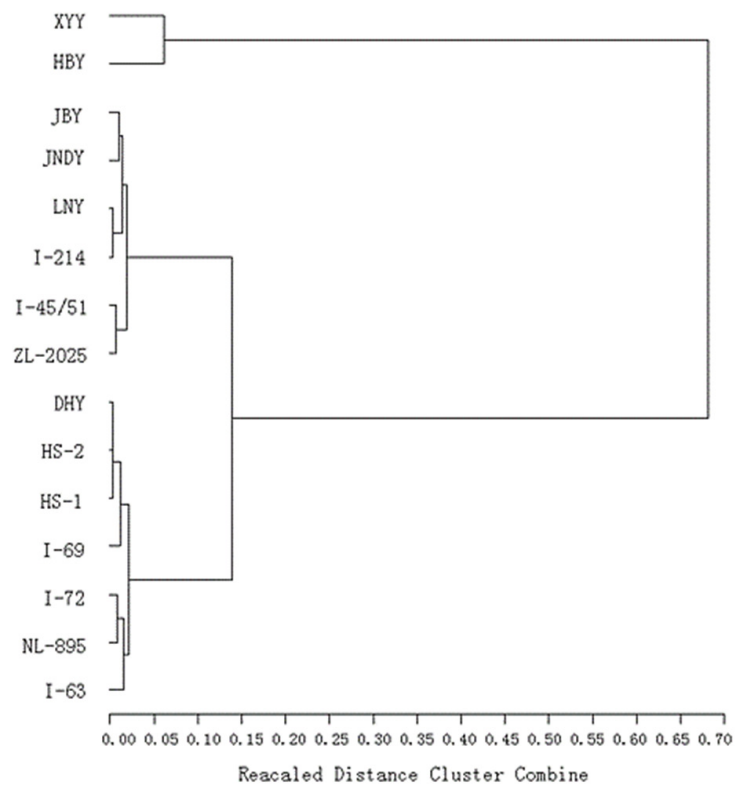

Figure 9. Cluster analysis dendrogram of the performance of the 15 clones under waterlogging stress

\section{Membership function analysis}

According to the parameters used in cluster analysis of waterlogging tolerance, membership function values of the 15 poplar clones were calculated (Table 3). The results showed that HS-1 owned the highest average membership value (0.637), followed by NL-895 (0.620), and XYY had the lowest one (0.436). Identical to the results of cluster analysis, membership function analysis showed that waterlogging tolerance of HS-1, NL-895, I-69, HS-2 and DHY were the best, while XYY and HBY were the worst.

Table 3. Membership function values of the 15 poplar clones under waterlogging treatment

\begin{tabular}{|c|c|c|c|c|c|c|c|c|c|c|c|c|}
\hline \multirow{2}{*}{ Clones } & \multicolumn{10}{|c|}{ Membership function values } & $\begin{array}{c}\text { Average } \\
\text { Membership } \\
\text { function } \\
\text { values }\end{array}$ \\
\cline { 2 - 15 } & Height & $\begin{array}{c}\text { Ground } \\
\text { diameter }\end{array}$ & Biomass & $\begin{array}{c}\text { Root/shoot } \\
\text { ratio }\end{array}$ & $P_{n}$ & $G s$ & $T_{r}$ & $C_{i} / C_{a}$ & $F_{V}$ & $F_{V} / F_{O}$ & $F_{V} / F_{m}$ & 0.436 \\
\hline XXY & 0.344 & 0.377 & 0.464 & 0.275 & 0.472 & 0.337 & 0.486 & 0.534 & 0.476 & 0.391 & 0.643 & 0.467 \\
\hline HBY & 0.372 & 0.375 & 0.445 & 0.370 & 0.479 & 0.494 & 0.510 & 0.538 & 0.485 & 0.552 & 0.511 & 0.483 \\
\hline I-214 & 0.444 & 0.500 & 0.400 & 0.654 & 0.404 & 0.433 & 0.348 & 0.620 & 0.517 & 0.529 & 0.465 & 0.573 \\
\hline LNY & 0.402 & 0.506 & 0.466 & 0.581 & 0.592 & 0.383 & 0.651 & 0.410 & 0.536 & 0.626 & 0.478 & 0.512 \\
\hline $\begin{array}{c}\text { I- } \\
\text { 45/51 }\end{array}$ & 0.389 & 0.421 & 0.445 & 0.515 & 0.564 & 0.550 & 0.617 & 0.551 & 0.525 & 0.526 & 0.541 & 0.513 \\
\hline JBY & 0.563 & 0.550 & 0.319 & 0.538 & 0.455 & 0.491 & 0.624 & 0.639 & 0.418 & 0.470 & 0.590 & 0.514 \\
\hline $\begin{array}{c}\text { ZL- } \\
\text { 2025 }\end{array}$ & 0.377 & 0.438 & 0.475 & 0.563 & 0.651 & 0.558 & 0.645 & 0.384 & 0.602 & 0.587 & 0.427 & 0.519 \\
\hline JNDY & 0.640 & 0.448 & 0.537 & 0.525 & 0.628 & 0.562 & 0.610 & 0.404 & 0.508 & 0.607 & 0.532 & 0.546 \\
\hline I-72 & 0.657 & 0.617 & 0.613 & 0.615 & 0.460 & 0.542 & 0.606 & 0.538 & 0.516 & 0.496 & 0.623 & 0.571 \\
\hline I-63 & 0.650 & 0.610 & 0.550 & 0.618 & 0.466 & 0.620 & 0.559 & 0.362 & 0.636 & 0.596 & 0.630 & 0.572 \\
\hline HS-2 & 0.565 & 0.642 & 0.603 & 0.715 & 0.617 & 0.560 & 0.520 & 0.540 & 0.535 & 0.540 & 0.583 & 0.584 \\
\hline DHY & 0.690 & 0.601 & 0.593 & 0.732 & 0.516 & 0.520 & 0.546 & 0.656 & 0.579 & 0.549 & 0.529 & 0.592 \\
\hline I-69 & 0.726 & 0.647 & 0.584 & 0.714 & 0.621 & 0.605 & 0.576 & 0.599 & 0.535 & 0.586 & 0.594 & 0.617 \\
\hline $\begin{array}{c}\text { NL- } \\
895\end{array}$ & 0.745 & 0.664 & 0.727 & 0.719 & 0.616 & 0.651 & 0.576 & 0.588 & 0.479 & 0.533 & 0.519 & 0.620 \\
\hline HS-1 & 0.732 & 0.703 & 0.702 & 0.718 & 0.562 & 0.660 & 0.440 & 0.750 & 0.610 & 0.530 & 0.600 & 0.637 \\
\hline
\end{tabular}




\section{Discussion}

Lots of previous literatures reported that waterlogging stress would adversely affect morphology, anatomy, nutrient metabolism, hormone balance and photosynthetic performance in many plant species (Loreti et al., 2016). Soil hypoxia is the main cause of waterlogging injury (Voesenek and Bailey-Serres, 2013). Survival and growth of plants under waterlogging stress are closely related to the function of leaves and roots (Kreuzwieser and Rennenberg, 2014; Striker and Colmer, 2017). Under waterlogging stress, roots of plants were firstly damaged, followed by inhibited growth of aboveground parts, such as retarded leaf initiation and development, decreased growth of height and ground diameter, chlorosis and abscission of leaves, as well as reduction of biomass accumulation (Chen et al., 2010; Štícha et al., 2016). Waterlogging-tolerant plants always can relieve injury by changing their morphology and physiological metabolism (Bailey Serres and Voesenek, 2008; Bejaoui et al., 2012). It is generally believed that the characteristics of development of hypertrophied lenticels and adventitious roots, together with root aerenchyma formation are closely related to waterlogging tolerance of poplar (Kreuzwieser and Rennenberg, 2014; Peng et al., 2017). In the present study, the waterlogging-tolerant clones generally developed hypertrophied lenticels and adventitious roots earlier than waterlogging-susceptible clones. For instance, DHY, HS-1, HS-2, I-69, NL-895, I-72 and I-63 hypertrophied lenticels on day 5-6 of waterlogging treatment, and induced their adventitious roots on day 10-11. While, the corresponding time in XYY, HBY, LNY, I-45/51 and I-214 were day 6-7 and day 16-17, respectively. In hypertrophied lenticels and adventitious roots, abundant aerenchyma is helpful for plants to relieve injury by enhancing absorption of $\mathrm{O}_{2}$, water and nutrient elements from water, accompanied with release of $\mathrm{CO}_{2}, \mathrm{C}_{2} \mathrm{H}_{2}$, ethanol and other harmful substances (Pedersen et al., 2020). At the end of the experiment, all waterlogged plants of DHY, HS-1, HS-2, I-72, I-69, I-63 and NL-895 survived, and all waterlogged plants of XYY died, and survival rates of the other clones ranged from $33.33 \%$ to $83.33 \%$. That means these seven clones could endure long-term waterlogging stress, and XYY was the most waterlogging-susceptible.

In addition to survival rate, growth and biomass accumulation are important indicators of plant waterlogging tolerance as well. Under waterlogging stress, waterlogging-tolerant plants can maintain superior growth and biomass accumulation to susceptible ones (Cao et al., 1999; Gong et al., 2007; Peng et al., 2017). In our study, DHY, HS-1, HS-2, I-69 and NL-895 exhibited markedly higher waterlogging tolerance indexes compared to the other clones in growth and biomass accumulation, which indicated their superior vitality under waterlogging stress. The negative waterlogging tolerance index of ground diameter growth in XYY might due to the decay of stem base during waterlogging treatment, accompanied with the shrink during the recovery stage. A lower root/shoot ratio reflected the greater reduction in root than shoot growth, which mainly resulted from the decay of the original root system and the inhibition of new root growth (Liu and Dickmann, 1992; Zhou et al., 2019). In our study, waterlogging-tolerant clones generally owned higher root/shoot ratios than waterlogging-sensitive clones, in accordance with those reported in the literatures (Rodriguez et al., 2020).

Gas exchange reflects metabolism activities of plants (Chen et al., 2005). Stomatal closure is one of the earliest responses of plants to waterlogging stress, which can reduce the rate of water loss and relieve waterlogging injury (Blanke and Cooke, 2004; Rood et al., 2010). Waterlogging induced Gs decrease is usually associated with variation of hormone levels in plants, especially the increased concentration of abscisic acid (ABA) (Jackson et al., 2003). Accompanied with the decrease of $G s$, values of $P_{n}, T_{r}$ and $C i / C a$ changed correspondingly as well (Mielke et al., 2005). In the present study, the leaf gas exchange parameters of all clones decreased in varying levels with the prolonged waterlogging, which was not only related to the waterlogging induced damage of photosynthetic system, but also related to the reduced chlorophyll contents and premature leaf senescence (Sena and Kozlowski, 1980). Waterlogging-tolerant plants generally have higher leaf gas exchange parameters under waterlogging stress compared to waterlogging-sensitive plants (Du et al., 2010; Liu et al., 2011). In our study, the leaf gas exchange parameters of DHY, HS-1, HS-2, I-69 and NL-895 were remarkably less inhibited by waterlogging stress than those of XYY, HBY and the other clones. Therefore, they can survive after the long-term waterlogging stress, and maintain higher growth rate and biomass accumulation. 
Chlorophyll fluorescence is the remission of energy absorbed by photosynthetic pigments, which was widely used as a sensitive measure of stress induced damage to PSII (Kozlowski et al., 1984). FV, $F_{V} / F m$ and $F_{V} / F_{O}$ are three important parameters to reveal the photochemical reactions of plants (Bilger et al., 1995). Among them, $F_{V}$ reflects the reduction of $\mathrm{Q}_{\mathrm{A}}$ (primary quinone-type electron acceptor of PS II ); $F_{V} / F_{F}$ reflects the potential activity of PS II in leaves; $F_{V} / F m$ represents the maximum photochemical efficiency of PS II in leaves. It has been reported previously that $F_{V}, F_{V} / F_{m}$ and $F_{V} / F_{O}$ decrease when plants are suffering from waterlogging stress (Smethurst et al., 2005). The greater reduction levels usually reflect more severe damage to PS II (Du et al., 2010; Peng et al., 2017). In this study, $F_{V}, F_{V} / F_{m}$ and $F_{V} / F_{O}$ values in all of the 15 clones pronouncedly decreased with the prolonged waterlogging. While, DHY, HS-1, HS-2, I-69 and NL-895 exhibited less decreased values and better recovery abilities than the other clones. That means DHY, HS-1, HS2, I-69 and NL-895 suffered slighter waterlogging injury among the 15 clones, which was in accordance with their leaf gas exchange parameters.

\section{Conclusions}

The waterlogging tolerance of plants is a complicated quantitative trait, which involved in characteristics of morphology, anatomy and physiology. Therefore, multi-indicator evaluation is necessary to accurately reflect waterlogging tolerance of plants (Zhou et al., 2019). In this study, we evaluated waterlogging tolerance of the 15 clones by cluster analysis and membership function analysis, respectively, based on the parameters of their survival rate, growth of height and ground diameter, biomass accumulation, leaf gas exchange and chlorophyll fluorescence. Results of the both analysis methods showed that HS-1, I-69, DHY, NL-895 and HS-2 had the strongest waterlogging tolerance, XYY and HBY were the worst, and the other clones were moderate. Therefore, these waterlogging-tolerant clones should be selected preferentially for afforestation and breeding for waterlogging resistance in Jianghan Plain.

\section{Authors' Contributions}

Implementation of the experiment: RN G, Q H and TH N; Provision of experimental materials: XY Z and XP Z; Writing - original draft: RN G and XY Z; Writing - review and editing: KB D; Methodology: KB D; Data curation: RN G; Formal analysis: XYZ.

All authors read and approved the final manuscript.

\section{Acknowledgements}

Acknowledgements: This work was supported by the National Natural Science Foundation of China (grant number 31570665), and the Fundamental Research Funds for the Central Universities (grant number 2662020YLPY017).

\section{Conflict of Interests}

The authors declare that there are no conflicts of interest related to this article. 


\section{References}

Azizi S, Tabari M, Striker GG (2017). Growth, physiology, and leaf ion concentration responses to long-term flooding with fresh or saline water of Populus euphratica. South African Journal of Botany 108:229-236. https://doi.org/10.1016/j.sajb.2016.11.004

Bailey-Serres J, Voesenek L (2008). Flooding stress: acclimations and genetic diversity. Annual Review of Plant Biology 59:313-339. https://doi.org/10.1146/annurev.arplant.59.032607.092752

Bejaoui Z, Albouchi A, Lamhamedi MS, Abassi M, Aouni MHE (2012). Adaptation and morpho-physiology of three Populus deltoides Marsh. $\times$ P. nigra L. clones after preconditioning to prolonged waterlogging. Agroforestry Systems 86(3):433-442. https://doi.org/10.1007/s10457-012-9487-7

Bilger W, Schreiber U, Bock M (1995). Determination of the quantum efficiency of photosystem II and of nonphotochemical quenching of chlorophyll fluorescence in the field. Oecologia 102(4):425-432. http://doi.org/10.1007/BF00341354

Blanke MM, Cooke DT (2004). Effects of flooding and drought on stomatal activity, transpiration, photosynthesis, water potential and water channel activity in strawberry stolons and leaves. Plant Growth Regulation 42: 153-160. https://doi.org/10.1023/B:GROW.0000017489.21970.d4

Cao FL, Conner WH (1999). Selection of flood-tolerant populus deltoides clones for reforestation projects in China. Forest Ecology and Management 117(1-3):211-220. https://doi.org/10.1016/S0378-1127(98)00465-4

Chen LY, Du KB, Jiang FX, Peng YJ, Tu BK, Wamg X (2015). Influences of waterlogging stress on cell structure of primary roots of two poplar species. Scientia Silvae Sinicae 3:163-169. http://en.cnki.com.cn/Article_en/CJFDTOTAL-LYKE201503021.htm

Chen H, Qualls RG, Blank RR (2005). Effect of soil flooding on photosynthesis, carbohydrate partitioning and nutrient uptake in the invasive exotic Lepidium latifolium. Aquatic Botany 82(4):250-268. https://doi.org/10.1016/j.aquabot.2005.02.013

Chen H, Zamorano MF, Ivanoff D (2010). Effect of flooding depth on growth, biomass, photosynthesis, and chlorophyll fluorescence of Typha domingensis. Wetlands 30(5):957-965. https://doi.org/10.1007/s13157-010-0094-y

Correia O, Barradas MCD (2000). Ecophysiological differences between male and female plants of Pistacia lentiscus $\mathrm{L}$. Plant Ecology 149(2):131-142. https://doi.org/10.1023/A:1026588326204

$\mathrm{Du} \mathrm{KB}$, Shen BX, Xu L, Tu BK (2008). Estimation of genetic variances in flood tolerance of poplar and selection of resistant F1 generations. Agroforestry Systems 74(3):243-257. https://doi.org/10.1007/s10457-008-9112-y

Du KB, Xu L, Tu BK, Shen BX (2010). Influences of soil flooding on ultrastructure and photosynthetic capacity of leaves of one-year old seedlings of two poplar clones. Scientia Silvae Sinicae 46(6):58-64. http://en.cnki.com.cn/Article_en/CJFDTOTAL-LYKE201006010.htm

Gong JR, Zhang XS, Huang YM, Zhang CL (2007). The effects of flooding on several hybrid poplar clones in Northern China. Agroforestry Systems 69(1):77-88. https://doi.org/10.1007/s10457-006-9019-4

He YY, Wang CY, Yuan ZX, Li XX, Yang WH, Song H, Li CX (2018). Photosynthetic characteristics of Taxodium ascendens and Taxodium distichum under different submergence in the hydro-fluctuation belt of the Three Gorges Reservoir. Acta Ecologica Sinica 8:2722-2731. http://en.cnki.com.cn/Article_en/CJFDTOTALSTXB201808011.htm

Jackson MB, Saker LR, Crisp CM, Else MA, Janowiak F (2003). Ionic and pH signalling from roots to shoots of flooded tomato plants in relation to stomatal closure. Plant Soil 253:103-113. https://doi.org/10.1023/A:1024588532535

Jiang XM, Hu JY, Qi WH, Chen GD, Xu X (2009). Different physiological responses of male and female Ginkgo biloba (Ginkgoaceae) seedlings to salt stress. Acta Botanica Yunnanica 31(5):447-453. https://doi.org/10.3724/SP.J.1143.2009.09049

Kozlowski TT, Pallardy SG (1984). Effect of flooding on water, carbohydrate, and mineral relations. Flooding and Plant Growth 165-193. http://dx.doi.org/10.1016/B978-0-12-424120-6.50010-9

Kreuzwieser J, Rennenberg H (2014). Molecular and physiological responses of trees to waterlogging stress. Plant Cell Environ 37:2245-2259. https://doi.org/10.1111/pce.12310

Liu Z, Dickmann DI (1992). Responses of two hybrid poplar clones to flooding, drought, and nitrogen availability: I. Morphology and growth. Canadian Journal of Botany 70:2265-2270. https://doi.org/10.1139/b92-281

Liu JL, Wu ZN, Yu YS, Su XH (2014). The waterlogging resistance of 'Jianghuai' poplar cultivars. Journal of Forestry Engineering 28(6):25-29. http://dx.doi.org/10.13360/j.issn.1000-8101.2014.06.006 
Liu YL, Wang QC, Yang YB, Sun XX (2011). Effects of water stress on growth and photosynthetic characteristics of red pine seedlings. Journal of Northeast Forestry University 39(4):33-36. http://dx.doi.org/10.13759/j.cnki.dlxb.2011.04.038

Loreti E, van Veen H, Perata P (2016). Plant responses to flooding stress. Current Opinion in Plant Biology 33:64-71. http://dx.doi.org/10.1016/j.pbi.2016.06.005

Mielke MS, Almeida de AAF, Gomes FP, Mangabeira PAO, Silva DDC (2005). Effects of soil flooding on leaf gas exchange and growth of two neotropical pioneer tree species. New Forest 29:161-168. http://dx.doi.org/10.1007/s11056-005-0247-7

Pedersen O, Nakayama Y, Yasue H, Kurokawa Y (2020). Lateral roots, in addition to adventitious roots, form a barrier to radial oxygen loss in Zea nicaraguensis and a chromosome segment introgression line in maize. New Phytologist 229(1):5-7. http://doi.org/10.1111/nph.16452

Peng YJ, Zhou ZX, Zhang Z, Yu XL, Zhang XY, Du KB (2018). Molecular and physiological responses in roots of two full-sib poplars uncover mechanisms that contribute to differences in partial submergence tolerance. Scientific Reports 8:12829. http://dx.doi.org/10.1038/s41598-018-30821-y

Peng YJ, Zhou ZX, Tong RG, Hu XY, Du KB (2017). Anatomy and ultrastructure adaptations to soil flooding of two full-sib poplar clones differing in flood-tolerance. Flora 233:90-98. http://dx.doi.org/10.1016/j.flora.2017.05.014

Rodriguez ME, Lauff D, Cortizo S, Luquez VMC (2020). Variability in flooding tolerance, growth and leaf traits in a Populus deltoides intraspecific progeny. Tree Physiology 40(1):19-29. https://doi.org/10.1093/treephys/tpz128

Rood SB, Nielsen, JL, Shenton L, Gill KM, Letts MG (2010). Effects of flooding on leaf development, transpiration, and photosynthesis in narrowleaf cottonwood, a willow-like poplar. Photosynthesis Research 104:31-39. https://doi.org/10.1007/s11120-009-9511-6

Sena Gomes AR, Kozlowski TT (1980). Growth responses and adaptations of Fraxinus pennsylvanica seedlings to flooding. Plant Physiology 66(2):267-271. https://doi.org/10.1104/pp.66.2.267

Smethurst CF, Garnett T, Shabala S (2005). Nutritional and chlorophyll fluorescence responses of lucerne (Medicago sativa) to waterlogging and subsequent recovery. Plant Soil 270:31-45. http://dx.doi.org/doi:10.1007/s11104$004-1082-x$

Štícha V, Macků J, Nuhlíček O (2016). Effect of permanent waterlogging on the growth of poplar clones MAX 4, MAX 5 (J-104, J-105) (Populus maximowiczii A. Henry $\times$ P. nigra Linnaeus) and evaluation of wood moisture content in different stem parts - short communication. Journal of Forest Science 62:186-190. https://doi.org/10.17221/90/2015-JFS

Striker GG, Colmer TD (2017). Flooding tolerance of forage legumes. Journal of Experimental Botany 68(1851):1851. http://dx.doi.org/10.1093/jxb/erw239

Sun H, Wu ZN, Liu JL, Miao TT, Cao ZH (2020). Effects of water stress on growth and physiological properties of four poplar varieties. Journal of West China Forestry Science 49(2):62-67. https://doi.org/10.16473/j.cnki.xblykx1972.2020.02.010

Voesenek LACJ, Bailey-Serres J (2013). Flooding tolerance: $\mathrm{O}_{2}$ sensing and survival strategies. Current Opinion in Plant Biology 16:647-653. http://dx.doi.org/10.1016/j.pbi.2013.06.008

Yan C, Song S, Wang W, Wang C, Li H, Wang F, Li S, Sun X (2020). Screening diverse soybean genotypes for drought tolerance by membership function value based on multiple traits and drought tolerant coefficient of yield. BMC Plant Biology 20:321. https://doi.org/10.1186/s12870-020-02519-9

Yan Z, Zhang JT, Zhao PH, Yang SH, Ma YT, Zhu D (2019). Effects of continuous waterlogging stress on growth, physiology and biochemistry of Populus deltoides seedlings. Journal of Central South University of Forestry \& Technology 39(12):16-23. https://doi.org/10.14067/j.cnki.1673-923x.2019.12.003

Yang P, Xu X (2012). Effects of waterlogging stress on the growth and physiological characteristics of male and female Populus cathayana seedlings. Chinese Journal of Plant Ecology 36(1):81-87. http://en.cnki.com.cn/Article_en/CJFDTOTAL-ZWSB201201012.htm

Zhao XJ, Cheng F, Zhang K, Huang KD, Ni Y, Meng X, Tang LZ (2019). Root morphology of different poplar clone stecklings under waterlogging and flooding treatment. Journal of Nanjing Forestry University 43(5):1-8. http://en.cnki.com.cn/Article_en/CJFDTotal-NJLY201905001.htm 
Zhou ZC, Li G, Sun XM, Xu F, Chen ZX (2019). Physiological responses and tolerance evaluation of five poplar varieties to waterlogging. Notulae Botanicae Horti Agrobotanici Cluj-Napoca 47(3):658-667. https://doi.org/10.15835/nbha47311440

OPEN ACCESS

(c) (i)
The journal offers free, immediate, and unrestricted access to peer-reviewed research and scholarly work. Users are allowed to read, download, copy, distribute, print, search, or link to the full texts of the articles, or use them for any other lawful purpose, without asking prior permission from the publisher or the author.

License - Articles published in Notulae Botanicae Horti Agrobotanici Cluj-Napoca are Open-Access, distributed under the terms and conditions of the Creative Commons Attribution (CC BY 4.0) License.

(c) Articles by the authors; UASVM, Cluj-Napoca, Romania. The journal allows the author(s) to hold the copyright/to retain publishing rights without restriction. 
Supplementary Files

Supplementary Table 1 . The waterlogging tolerance indexes of the 15 poplar clones (\%)

\begin{tabular}{|c|c|c|c|c|c|c|c|}
\hline \multirow{2}{*}{ Clone } & \multirow{2}{*}{$\begin{array}{l}\text { Seedling } \\
\text { height }\end{array}$} & \multirow{2}{*}{$\begin{array}{l}\text { Ground } \\
\text { diameter }\end{array}$} & \multicolumn{4}{|c|}{ Biomass } & \multirow{2}{*}{$\begin{array}{c}\text { Total } \\
\text { biomass }\end{array}$} \\
\hline & & & Root & Stem & Leaf & $\begin{array}{l}\text { Root/shoot } \\
\text { ratio }\end{array}$ & \\
\hline XYY & 37.56 & -9.63 & 7.25 & 30.45 & 0 & 53.85 & 12.54 \\
\hline JBY & 62.27 & 71.68 & 45.77 & 67.70 & 77.22 & 64.86 & 65.09 \\
\hline JNDY & 62.11 & 62.67 & 47.45 & 67.25 & 78.51 & 65.71 & 65.96 \\
\hline $\mathrm{HBY}$ & 42.06 & 45.10 & 16.50 & 34.90 & 30.60 & 50.00 & 28.50 \\
\hline DHY & 85.63 & 85.36 & 73.60 & 82.72 & 84.45 & 86.96 & 80.42 \\
\hline LNY & 69.26 & 67.04 & 46.06 & 75.00 & 67.95 & 63.89 & 64.86 \\
\hline HS-1 & 87.32 & 83.63 & 73.41 & 83.61 & 84.18 & 88.37 & 80.69 \\
\hline HS-2 & 87.14 & 82.94 & 70.59 & 83.75 & 75.97 & 88.24 & 76.97 \\
\hline $\mathrm{I}-72$ & 74.83 & 73.41 & 62.01 & 76.69 & 70.43 & 84.62 & 70.11 \\
\hline$I-69$ & 79.66 & 80.07 & 73.23 & 85.37 & 81.72 & 88.24 & 81.23 \\
\hline I-63 & 79.63 & 76.77 & 65.55 & 82.32 & 82.00 & 78.12 & 78.15 \\
\hline $\mathrm{I}-45 / 51$ & 60.86 & 68.84 & 44.86 & 63.00 & 62.88 & 71.43 & 56.96 \\
\hline I-214 & 61.17 & 73.23 & 53.17 & 79.28 & 75.41 & 68.63 & 69.21 \\
\hline NL-895 & 84.59 & 78.55 & 71.02 & 86.20 & 72.85 & 88.24 & 77.28 \\
\hline ZL2025 & 60.86 & 69.43 & 49.82 & 73.92 & 70.06 & 68.42 & 65.90 \\
\hline
\end{tabular}

Supplementary Table 2. The waterlogging tolerance indexes of leaf gas exchange and chlorophyll fluorescence parameters in the 15 poplar clones after 45 -day waterlogging treatment (\%)

\begin{tabular}{|l|c|c|c|c|c|c|c|}
\hline \multicolumn{1}{|c|}{ Clones } & $P_{n}$ & $G s$ & $T r$ & $C_{i} / C_{a}$ & $F_{V}$ & $F_{V} / F_{O}$ & $F_{V} / F_{m}$ \\
\hline XYY & 17.49 & 19.11 & 20.24 & 66.89 & 66.02 & 71.34 & 79.10 \\
\hline JBY & 73.09 & 71.76 & 68.67 & 99.11 & 70.39 & 70.77 & 74.00 \\
\hline JNDY & 51.21 & 73.89 & 82.10 & 98.69 & 71.61 & 79.94 & 86.61 \\
\hline HBY & 29.73 & 21.74 & 34.55 & 79.89 & 73.99 & 39.08 & 78.76 \\
\hline DHY & 69.41 & 63.88 & 76.00 & 96.96 & 92.61 & 84.78 & 88.67 \\
\hline LNY & 47.44 & 58.48 & 66.12 & 92.60 & 72.74 & 76.08 & 81.06 \\
\hline HS-1 & 66.91 & 77.62 & 68.73 & 93.86 & 85.83 & 81.72 & 96.21 \\
\hline HS-2 & 62.31 & 62.55 & 69.67 & 89.18 & 88.11 & 79.51 & 95.93 \\
\hline I-72 & 68.03 & 64.70 & 67.15 & 97.67 & 86.29 & 71.80 & 99.13 \\
\hline I-69 & 83.97 & 72.01 & 86.23 & 94.76 & 87.09 & 92.51 & 99.73 \\
\hline I-63 & 51.21 & 67.24 & 81.00 & 98.11 & 74.19 & 76.99 & 79.36 \\
\hline I-45/51 & 64.38 & 51.61 & 51.77 & 98.17 & 66.81 & 66.88 & 79.95 \\
\hline I-214 & 45.70 & 61.30 & 62.32 & 94.39 & 68.73 & 78.39 & 71.02 \\
\hline NL-895 & 55.07 & 62.04 & 51.55 & 92.17 & 88.11 & 64.99 & 88.36 \\
\hline ZL-2025 & 51.45 & 57.99 & 54.01 & 91.21 & 80.94 & 68.14 & 93.17 \\
\hline
\end{tabular}

